\title{
Erratum to: The characterisation of three different coal samples by means of various analytical techniques
}

\author{
F. B. Waanders • J. C. van Dyk • C. B. Prinsloo
}

Published online: 3 December 2009

(c) Springer Science + Business Media B.V. 2009

\section{Erratum to: Hyperfine Interact (2009) 190:109-114 DOI 10.1007/s10751-009-9971-2}

Due to an unfortunate turn of events this article has been published in Hyperfine Interactions Volume 190, pp 109-114 with an erroneous version of one of the three authors' names. Please find below the correct list of authors that should be regarded by the reader as the final version.

\section{F. B. Waanders • J. C. van Dyk • C. B. Prinsloo}

The online version of the original article can be found at http://dx.doi.org/10.1007/s10751-009-9971-2.

F. B. Waanders $(\varangle)$. C. B. Prinsloo

North-West University, Potchefstroom, 2531, South Africa

e-mail: frans.waanders@nwu.ac.za

J. C. van Dyk

Sasol Technology, R\&D Division,

Syngas and Coal Technologies, P.O. Box 1,

Sasolburg, 1947, South Africa 